\title{
Contents/Sommaire
}

\section{David Herman}

On the semantic status of film: Subjectivity, possible worlds, transcendental semiotics

Patrick Imbert

Peace and war: Public language, specialized language, and the media

Ann Rigney

Fame and defamation: Toward a socio-pragmatics

Raivo Vetik

The Platonism of J. Lotman

James $F$. Weiner

Convention, motivation, and resistance in discourse with reference to Foi myth

\section{Review articles/Comptes rendus}

Floyd Merrell

On bifurcating semiosis: or, How to stop worrying about those elusive signs and learn to live with them

George W. Stickel

Ilow perfuse and pervasive are signs in the videring of

complexity and becoming in the universe?

Naomi S. Baron

Do words have meanings? Dictionaries, definitions, and context

William P. Dougherty

The quest for interpretants: Toward a Peircean paradigm for musical semiotics

Jacques Fontanille

Des simulacres de l'énonciation à la praxis énonciative 
Dragan Milovanovic

Semiotics, Peirce, and law

Ivan Mladenov

Polyphonic reading...

Alice G. B. ter Meulen

Representing meaning: Magic or logic?

Roy Wagner

The longhouse of language

W. C. Watt

In the beginning 